\title{
DAMPAK PANDEMI COVID-19 TERHADAP PEREKONOMIAN MASYARAKAT DI SEKTOR INFORMAL
}

\section{THE IMPACT OF PADEMIC COVID-19 TOWARDS COMMUNITY ECONOMY AT INFORMAL SECTOR}

\author{
Rizal Fahlefi \\ Fakultas Ekonomi dan Bisnis Islam IAIN Batusangkar \\ Jl. Sudirman No. 137 Lima Kaum Batusangkar \\ rizalfahlefi@iainbatusangkar.ac.id \\ Shofian Ahmad \\ Fakulti Pengkajian Islam Universitas Kebangsaan Malaysia \\ Bangi, Selangor, Malaysia \\ shofian@ukm.edu.my \\ Rizal \\ Fakultas Ekonomi dan Bisnis Islam IAIN Batusangkar \\ Jl. Sudirman No. 137 Lima Kaum Batusangkar \\ rizal@iainbatusangkar.ac.id
}

Naskah diterima 13 Juli 2020, di-review 17 September 2020, disetujui 31 Desember 2020

\begin{abstract}
Pandemic Covid-19 has greater impact on people's lives in all aspects, including economy. The large-scale social restriction policy (PSBB) implemented by the government has restricted the movement of people from one place to another. Then it is suggested to work from home, study from home, or shop from home. As a result, informal sector businesses particularly transportation sub-sector. This research aims to see the impact of Covid-19 pandemic on the economy of people who work in the informal sector, especially the transportation sub-sector. This research was conducted in Tanah Datar Regency, West Sumatra Province in the second quarter of 2020. The population was public transportation workers and sample was minibus taxi drivers or motor taxi bikers. The data collected through a questionnaire, presented in table form and analyzed descriptively by using statistics. The results show Pandemic Covid-19 affect their income. The income of workers in this subsector decreased by $56 \%$ so that some workers chose to leave this job or switch to other jobs. This condition results in unfulfilled household needs, so they have to use existing savings, do savings, and rely on special assistance in handling Covid-19, even some wives have also had to work to help the family economy.
\end{abstract}

Keywords: Covid-19, Impact, Economy, Informal Sector, Transportation.

Abstrak: Pandemi covid-19 berdampak pada kehidupan masyarakat di semua aspek, termasuk perekonomian. Kebijakan Pembatasan Sosial Berskala besar (PSBB) yang diberlakukan telah membatasi pergerakan orang dari satu tempat ke tempat lain, ditambah lagi dengan gerakan bekerja dari rumah (work from home), belajar dari rumah (study from home), atau belanja dari rumah (shop from home). Pembatasan pergerakan ini mengakibatkan usaha sektor informal khususnya subsektor transportasi paling besar terkena dampaknya. Penelitian ini bertujuan untuk mengetahui dampak pandemi covid-19 terhadap perekonomian masyarakat yang bekerja di sektor informal khususnya subsektor transportasi. Penelitian ini dilakukan di Kabupaten Tanah Datar Provinsi Sumatera Barat pada kuartal kedua tahun 2020. Populasi penelitian adalah pekerja di sektor informal subsektor transportasi dengan sampel terdiri dari sopir angkot dan ojek. Data penelitian dikumpulkan melalui angket kemudian disajikan 
dalam bentuk tabel dan dianalisis dengan statistik deskriptif menggunakan persentase. Hasil penelitian menunjukkan bahwa pandemi covid-19 berdampak terhadap perekonomian masyarakat yang bekerja di sektor informal khususnya subsektor transportasi. Penghasilan pekerja di subsektor ini menurun sebesar 56\% sehingga sebagian pekerja memilih untuk meninggalkan pekerjaan ini atau beralih ke pekerjaan lain. Kondisi ini mengakibatkan tidak terpenuhinya kebutuhan rumah tangga, sehingga mereka harus menggunakan tabungan yang ada, melakukan penghematan, dan mengandalkan bantuan khusus penanganan covid-19, bahkan sebagian isteri juga terpaksa harus bekerja untuk membantu perekonomian keluarga.

Kata Kunci: Covid-19, Dampak, Ekonomi, Sektor Informal, Transportasi.

\section{PENDAHULUAN}

P andemi covid-19 telah menyebar ke seluruh dunia. Di Indonesia, covid-19 juga telah menyebar di 34 provinsi. Meskipun terdapat pasien yang sembuh, namun tidak sedikit juga yang harus terbunuh oleh virus tersebut. Meskipun berbagai usaha telah dilakukan, namun pandemi covid-19 di Indonesia belum juga bisa dibasmi. Setiap harinya, jumlah konfirmasi positif covid-19 masih terus bertambah. Mulai dari awalnya hanya penambahan beberapa orang saja per harinya sampai akhirnya menjadi puluhan, ratusan, dan bahkan ribuan kasus positif baru setiap hari.

Covid-19 ini sungguh mengerikan bagi semua orang karena kemampuannya untuk menular melalui percikan air ludah, sementara sebagai makhluk sosial hal inilah yang sangat sulit untuk dihindari karena setiap orang butuh bersosialisasi dengan orang lain. Kebijakan social distancing dan physical distancing yang diterapkan juga tidak mampu serta-merta memutus mata rantai penyebaran covid-19, karena banyak sisi kehidupan manusia yang mengharuskannya bertatap muka dengan orang lain.

Pandemi covid-19 telah mengubah tatanan kehidupan masyarakat. Berbagai agenda yang telah dijadwalkan terpaksa harus ditunda atau bahkan dibatalkan karena dikhawatirkan akan semakin memicu penyebaran covid-19. Begitu juga dengan kegiatan-kegiatan penting lain seperti pembelajaran, perkantoran, pertemuan, atau perjalanan harus dihentikan dengan tujuan untuk menghentikan penyebaran covid-19 dan menyelamatkan masyarakat dari terpapar virus tersebut.

Kebijakan berupa PSBB (Pembatasan Sosial Berskala besar) atau dikenal juga dengan istilah lockdown yang sempat diberlakukan telah membatasi pergerakan orang dari satu tempat ke tempat lain. Ditambah lagi, gerakan bekerja dari rumah (work from home), belajar dari rumah (study from home), atau belanja dari rumah (shop from home) semakin mengurangi pergerakan orang. Bahkan, silaturrahmi yang notabene adalah kegiatan temu ramah dengan saudara atau sesama juga disarankan dilakukan secara online.

Pandemi covid-19 berdampak pada kehidupan masyarakat di semua sektor termasuk perekonomian. Dirjend Pajak Kemenkeu, Suryo Utomo menyampaikan bahwa gejolak ekonomi akibat wabah covid-19 berakibat pada tiga dampak besar bagi perekonomian Indonesia. Pertama adalah membuat konsumsi rumah tangga atau daya beli jatuh cukup dalam, kedua menimbulkan adanya ketidakpastian yang 
berkepanjangan sehingga investasi ikut melemah dan berimplikasi pada terhentinya usaha, dan ketiga menyebabkan harga komoditas turun dan ekspor Indonesia ke beberapa negara juga terhenti karena seluruh dunia mengalami pelemahan ekonomi (Zuraya, 2020).

Dalam masa krisis ekonomi akibat pandemi covid-19 ini, masyarakat yang bekerja di sektor informal terdampak sangat buruk. Tempat-tempat usaha diperintahkan untuk ditutup sehingga banyak karyawan yang harus dirumahkan. Pembatasan pergerakan orang mengakibatkan tempat usaha yang masih diizinkan untuk dibuka menjadi kekurangan pelanggan sehingga merugi. Pembatasan pergerakan ini juga mengakibatkan usaha sektor informal khususnya subsektor transportasi paling besar terkena dampaknya.

Sektor transportasi adalah yang paling parah terdampak covid-19. Badan Pusat Statistik (BPS) mencatat bahwa ekonomi Indonesia pada kuartal dua tahun 2020 mengalami terkontraksi 5,32\%, dan kontraksi terdalam dialami sektor transportasi dan pergudangan yang menyumbang 3,57\% PDB (Thomas, 2020). Wakil Ketua Umum Kadin Bidang Perhubungan, Carmelita Hartoto juga mengatakan bahwa transportasi nasional menjadi salah satu sektor paling terdampak covid-19 (Azka, 2020).

Kondisi tersebut juga terjadi di Kabupaten Tanah Datar, Provinsi Sumatera Barat. Pekerja di sektor informal khususnya subsektor transportasi seperti sopir angkot dan tukang ojek juga terdampak akibat covid-19. Pembatasan pergerakan orang sehingga kegiatan lebih banyak dilakukan dari rumah, merupakan penyebab anjloknya usaha di sektor transportasi ini. Angkot dan ojek adalah sarana transportasi bagi masyarakat untuk melakukan kegiatan sehari-hari seperti bagi pelajar untuk berangkat ke sekolah, bagi karyawan untuk berangkat ke tempat bekerja, atau untuk berbelanja ke pasar guna berbelanja kebutuhan sehari-hari. Ketika adanya anjuran untuk melakukan kegiatan dari rumah baik belajar, bekerja, ataupun berbelanja selama pandemi covid-19, maka angkot dan ojek nyaris kehilangan penumpang.

Penelitian ini menyelidiki tentang dampak covid-19 terhadap perekonomian masyarakat sektor informal khususnya subsektor transportasi angkot dan ojek di Kabupaten Tanah Datar, Provinsi Sumatera Barat. Penelitian ini penting dilakukan karena sektor transportasi adalah sektor yang paling terdampak akibat covid-19 dan jumlah pekerja yang bergerak di sektor ini cukup banyak. Selain itu, hasil penelitian dapat menjadi dasar dalam memberikan stimulus ekonomi yang tepat bagi masyarakat terdampak covid-19.

Sejumlah penelitian telah membuktikan bahwa penyebaran virus dapat berdampak terhadap perekonomian. Dixon, McDonald, \& Roberts (2002) telah meneliti dampak virus HIV/AIDS terhadap perkembangan ekonomi di Afrika, begitu juga dengan Elci (2006) yang meneliti tentang dampak virus flu burung (H5N1) terhadap ekonomi negara-negara di Asia Tenggara. Qiu, Chu, Mao, \& Wu (2018) membandingkan dampak yang ditimbulkan oleh virus SARS pada tahun 2003 dan dampak virus H7N9 pada tahun 2013 terhadap kesehatan, sosial, dan ekonomi di China. Sementara itu, 
Smith, Machalaba, Seifman, Feferholtz, \& Karesh (2019) meneliti tentang dampak penyakit infeksi terhadap ekonomi di berbagai sektor.

Sejumlah penelitian juga telah dilakukan terkait dampak covid-19 terhadap perekonomian. Ezimma K., Ifeanyi E., \& Clara (2020) menyelidiki dampak pandemi covid-19 terhadap prospek ekonomi Nigeria di sektor informal dan mengusulkan strategi-strategi utuk mendukung sektor tersebut. Taufik \& Ayuningtyas (2020) juga telah meneliti tentang dampak pandemi covid-19 terhadap bisnis dan eksistensi platform online di Jakarta. Selain itu, sejumlah literature review juga telah dilakukan terkait dampak covid-19 tersebut terhadap perekonomian, seperti kajian yang dilakukan oleh Nicola et al. (2020) tentang dampak-dampak sosio-ekonomi yang ditimbulkan oleh pandemi covid-19; Ozili \& Arun (2020) tentang dampak social distancing terhadap kegiatan ekonomi dan indeks pasar saham; Ahmad, Haroon, Baig, \& Hui (2020) tentang dampak pandemi covid-19 terhadap ekonomi; dan Susilawati, Falefi, \& Purwoko (2020) menyelidiki tentang dampak covid-19 terhadap ekonomi Indonesia.

Berdasarkan penelusuran peneliti, penelitian empiris terkait dampak pandemi covid-19 terhadap perekonomian belum banyak dilakukan, sebagian besarnya bersifat literature review. Disamping itu, dari penelitian empiris yang telah dilakukan, juga belum ditemukan penelitian yang khusus tentang dampak pandemi covid-19 terhadap perekonomian sektor informal subsektor transportasi, padahal pekerja subsektor transportasi adalah yang paling terdampak oleh pandemi covid-19 dan jumlah pekerja yang 162|| Rizal Fahlefi, Shofian Ahmad, Rizal bekerja di subsektor ini juga sangat besar. Oleh karena itu, tujuan penelitian ini adalah untuk menyelidiki dampak pandemi covid-19 terhadap perekonomian masyarakat Kabupaten Tanah Datar, Provinsi Sumatera Barat di sektor informal khususnya subsektor transportasi.

\section{Kerangka Konseptual \\ COVID- 19}

Coronavirus adalah keluarga besar virus yang menyebabkan penyakit pada manusia dan hewan. Pada manusia biasanya menyebabkan infeksi saluran pernafasan, mulai flu biasa sampai pada penyakit yang serius MERS dan Sindrom Pernafasan Akut Berat (SARS). Coronavirus jenis baru yang ditemukan di Wuhan China, pada Desember 2019, kemudian diberi nama Severe Acute Respiratory Syndrome Coronvirus 2 (SARSCOV2) dan meyebabkan penykit COVID-19. (Diakses pada 01 Desember 2020, https:// stoppneumonia.id/informasi-tentang-viruscorona-novel-coronavirus/)

\section{Sektor Informal}

Sektor informal adalah sektor ekonomi yang terdiri atas unit usaha berskala kecil, yang memproduksi dan mendistribusikan barang dan jasa, dengan tujuan utama menciptakan kesempatan kerja dan kesempatan memperoleh pendapatan bagi para pelakunya. Kendala yang sering dihadapi oleh sektor ini adalah keterbatasan modal, fisik atau tenaga kerja, serta keterampilan. Sektor informal di negara-negara sedang berkembang, tumbuh dan berkembang sebagai akibat laju pertambahan angkatan kerja yang tinggi, serta ketidakmampuan sektor formal menyerapnya (Diakses pada 01 
Desember,2020,https://id.wikipedia.org/wiki/ Sektor_informal)

\section{METODE PENELITIAN}

Dalam penelitian ini, peneliti menggunakan metode survei. Penelitian ini dilakukan pada kuartal kedua (periode April-Juni) tahun 2020 di Kabupaten Tanah Datar Provinsi Sumatera Barat, Indonesia. Populasi penelitian terdiri dari pekerja di sektor informal subsektor transportasi. Adapun sampel penelitian terdiri dari 50 orang sopir angkot dan tukang ojek. Data penelitian dikumpulkan melalui angket. Data yang telah terkumpul disajikan dalam bentuk tabel kemudian dianalisis melalui statistik deskriptif menggunakan persentase.

\section{PEMBAHASAN DAN HASIL}

Pandemi covid-19 berdampak pada semua aspek kehidupan termasuk perekonomian. Para pekerja di sektor informal subsektor transportasi di Kabupaten Tanah Datar adalah sebagian dari masyarakat yang kondisi perekonomiannya terdampak oleh pandemi covid-19. Berdasarkan penelitian yang telah dilakukan terhadap responden yang bekerja pada subsektor transportasi tersebut, dapat penulis sajikan data-data pendudkung sebagai berikut:

Tabel 1.

Karakteristik Umur

\begin{tabular}{|c|l|l|l|}
\hline No & \multicolumn{1}{|c|}{ Umur } & \multicolumn{1}{c|}{ Jumlah } & Persentase \\
\hline 1 & $\leq 30$ & 11 & $22 \%$ \\
\hline 2 & $31-40$ & 12 & $24 \%$ \\
\hline 3 & $41-50$ & 14 & $28 \%$ \\
\hline 4 & $>50$ & 13 & $26 \%$ \\
\hline
\end{tabular}

Para pekerja di sektor informal subsektor transportasi berasal dari semua umur. Pekerja yang berumur 30 tahun ke bawah sebanyak 22\%, yang berumur 31-40 tahun sebanyak 24\%, yang berumur 41-50 tahun sebanyak 14\%, dan yang berumur lebih dari 50 tahun sebanyak 26\%. Berdasarkan data tersebut dapat diketahui bahwa pekerjaan di subsektor transportasi ini tergolong strategis untuk dilakukan oleh semua umur, tidak ada golongan umur yang mendominasi di sektor ini. Untuk kategori sopir, mayoritas para pekerja tersebut telah menekuninya dalam waktu yang cukup lama, sedangkan untuk kategori ojek mayoritas pekerja menekuninya karena menganggap hanya pekerjaan tersebut yang dapat mereka tekuni di saat mereka sulit mendapatkan pekerjaan lain.

Tabel 2.

Jumlah Tanggungan dalam Keluarga

\begin{tabular}{|c|l|l|l|}
\hline No & \multicolumn{1}{|c|}{ Jumlah Tanggungan } & \multicolumn{1}{c|}{ Jumlah } & \multicolumn{1}{c|}{ Persentase } \\
\hline 1 & $0-1$ & 10 & $20 \%$ \\
\hline 2 & $2-3$ & 19 & $38 \%$ \\
\hline 3 & $4-5$ & 17 & $34 \%$ \\
\hline 4 & $\geq 6$ & 4 & $8 \%$ \\
\hline
\end{tabular}


Para pekerja di sektor informal subsektor transportasi memiliki jumlah tanggungan yang bervariasi dalam keluarga mereka. Adapun 20\% pekerja memiliki 0-1 orang tanggungan dalam keluarga,38\% pekerja memiliki 2-3 orang tanggungan dalam keluarga, 34\% pekerja memiliki 4-5 tanggungan dalam keluarga, sedangkan 8\% pekerja memiliki 6 orangatau lebih tanggungan dalam keluarga. Dengan demikian dapat diketahui bahwa mayoritas pekerja tersebutadalah orang-orangyang tidak hanya bekerja untuk memenuhi kebutuhan dirinya sendiri, tetapi juga untuk memenuhi kebutuhan orang-orang yang menjadi tanggung jawabnya yang jumlahnya juga tidak sedikit.

Tabel 3.

Penghasilan Masa Pandemi Covid-19

\begin{tabular}{|c|l|l|l|}
\hline No & \multicolumn{1}{|c|}{ Penghasilan } & \multicolumn{1}{c|}{ Jumlah } & \multicolumn{1}{c|}{ Persentase } \\
\hline 1 & Tetap & 0 & $0 \%$ \\
\hline 2 & Turun $<50 \%$ & 9 & $18 \%$ \\
\hline 3 & Turun $\geq 50 \%$ & 35 & $70 \%$ \\
\hline 4 & Tidak ada penghasilan & 6 & $12 \%$ \\
\hline
\end{tabular}

Para pekerja di sektor informal subsektor transportasi tidak luput dari dampak pandemi covid-19, bahkan termasuk yang terparah terkena dampaknya. Ketika pandemi covid-19, penghasilan mereka menurun drastis, bahkan ada yang tidak memiliki penghasilan sama sekali dari sektor ini. Tidak ada pekerja (0\%) yang penghasilannya masih stabil selama pandemi covid-19, semua pekerja mengalami penurunan dan bahkan kehilangan penghasilan akibat pandemi tersebut.

Sebanyak $18 \%$ pekerja mengalami penurunan penghasilan kurang dari 50\% artinya mereka masih memperoleh penghasilan di atas $50 \%$ penghasilan sebelumnya, namun $70 \%$ dari pekerja mengalami penurunan penghasilan lebih dari
$50 \%$ artinya mereka berpenghasilan kurang dari $50 \%$ penghasilan sebelumnya. Bahkan, $12 \%$ dari pekerja tidak lagi memiliki penghasilan sama sekali. Berdasarkan data-data tersebut dapat disimpulkan bahwa pandemi covid-19 telah memberikan dampak penurunan penghasilan bagi pekerja di sektor informal subsektor transportasi di Kabupaten Tanah Datar.

Rata-rata penurunan penghasilan pekerja di sektor informal subsektor transportasi ini mencapai $56 \%$, artinya rata-rata para pekerja memperoleh penghasilan kurang dari setengah penghasilan pada situasi normal. Menyikapi kondisi tersebut, para pekerja mengambil keputusan yang berbeda-beda terkait dengan pekerjaan mereka.

Tabel 4.

Pekerjaan Masa Pandemi Covid-19

\begin{tabular}{|c|l|l|l|}
\hline No & \multicolumn{1}{|c|}{ Pekerjaan } & \multicolumn{1}{c|}{ Jumlah } & \multicolumn{1}{c|}{ Persentase } \\
\hline 1 & Tetap dengan pekerjaan sebelumnya & 31 & $62 \%$ \\
\hline 2 & $\begin{array}{l}\text { Tetap dengan pekerjaan sebelumnya dan ditambah } \\
\text { pekerjaan lain }\end{array}$ & 2 & $4 \%$ \\
\hline 3 & Beralih pada pekerjaan lain & 6 & $12 \%$ \\
\hline 4 & Tidak lagi memiliki pekerjaan & 11 & $22 \%$ \\
\hline
\end{tabular}


Meskipun dengan penghasilan yang sangat kecil, namun sebagian besar (62\%) pekerja masih bertahan dengan pekerjaannya di subsektor transportasi, sedangkan yang lain (4\%) berusaha menambah penghasilan dengan juga menekuni pekerjaan lain. Namun, $12 \%$ pekerja memilih meninggalkan pekerjaannya di subsektor transportasi ini dan beralih pada pekerjaan lain seperti bertani, berjualan, kuli, dan menawarkan jasa cuci gosok. Sebagian pekerja juga tidak lagi menggunakan kendaraan untuk jasa transportasi orang tetapi beralih untuk jasa mengantar pesanan makanan online. Bahkan, 22\% pekerja juga meninggalkan pekerjaannya tetapi tidak memiliki pekerjaan yang baru.

Untuk menutupi kekurangan penghasilan guna memenuhi kebutuhan sehari-hari, sebagian isteri juga terpaksa harus bekerja. Disamping itu, upaya yang dilakukan adalah dengan menggunakan tabungan yang ada, melakukan penghematan, dan mengandalkan bantuan covid-19. Namun demikian, tidak semua pekerja juga yang menerima bantuan khusus penanganan covid-19.

Tabel 5.

Bantuan yang Diterima Masa Pandemi Covid-19

\begin{tabular}{|c|l|l|l|}
\hline No & \multicolumn{1}{|c|}{ Bantuan yang diterima } & \multicolumn{1}{c|}{ Jumlah } & Persentase \\
\hline 1 & BLT \& Bantuan Lainnya & 16 & $32 \%$ \\
\hline 2 & BLT & 7 & $14 \%$ \\
\hline 3 & Bantuan Lainnya & 7 & $14 \%$ \\
\hline 4 & Tidak ada & 20 & $40 \%$ \\
\hline
\end{tabular}

Berdasarkan data tersebut dapat diketahui bahwa 16\% pekerja menerima Bantuan Langsung Tunai (BLT) dan juga bantuan lainnya selama pandemi covid-19, sebanyak 14\% pekerja menerima BLT saja, dan 14\% lainnya hanya menerima bantuan dalam bentuk paket sembako. Adapun $40 \%$ pekerja tidak pernah menerima bantuan apapun selama masa pandemi covid-19.

Perekonomian masyarakat, khususnya subsektor transportasi di Kabupaten Tanah Datar mengalami penurunan drastis akibat pandemi Covid-19. Meskipun sudah memasuki masa newnormal dan pemberlakukan PSBB sudah dicabut, akan tetapi baru sebagian aktivitas yang kembali dibuka, sedangkan sebagian lainnya masih belum diizinkan. Bahkan sampai akhir Agustus 2020, sekolah dan perguruan tinggi yang ada di Kabupaten Tanah Datar masih ditutup, sementara sebagian besar Aparatur Sipil Negara (ASN) dan karwayan masih bekerja dari rumah (work from home). Padahal pelajar, mahasiswa, ASN dan karyawan adalah pengguna layanan transportasi dengan persentase cukup besar. Kondisi tersebut tentu sangat berpengaruh terhadap penurunan penghasilan pekerja di sektor transportasi.

Hasil penelitian ini sejalan dengan temuan Taufik \& Ayuningtyas (2020) bahwa akibat diberlakukannya work from home (WFH), social distancing dan physical distancing sebagai bentuk pencegahan penyebaran pandemi covid-19, yang disertai dengan kebijakan pembatasan sosial berskala besar (PSBB), maka data menunjukkan terjadinya pengurangan aktivitas bisnis di DKI Jakarta, termasuk di sektor transportasi.

Hasil penelitian ini juga sesuai dengan temuan penelitian Perdana et al. (2020) bahwa kelompok masyarakat yang paling terpukul oleh krisis pandemi covid-19 ini adalah kelompok 
pekerja rentan yaitu mereka yang bekerja tak menentu berdasarkan kontrak, jam kerja, jaminan yang tak menentu. Hasil penelitiannya juga menyatakan bahwa semua responden pekerja rentan termasuk di dalamnya pengemudi ojek menyatakan bahwa omset pendapatan hingga penghasilan hariannya turun drastic.

\section{PENUTUP}

Pandemi covid-19 berdampak terhadap perekonomian masyarakat yang bekerja di sektor informal khususnya subsektor transportasi. Penghasilan pekerja di subsektor ini menurun sampai $56 \%$ sehingga sebagian pekerja meninggalkan pekerjaan ini atau beralih ke pekerjaan lain seperti bertani, berjualan, kuli, dan cuci gosok. Kondisi ini mengakibatkan kebutuhan rumah tangga mereka tidak terpenuhi, sehingga mereka harus menggunakan tabungan yang ada, melakukan penghematan, dan mengandalkan bantuan khusus penanganan covid-19, bahkan sebagian isteri juga terpaksa harus bekerja untuk membantu perekonomian keluarga.

Kondisi tersebut seharusnya menjadi perhatian semua pihak, terutama pemerintah daerah dan pemerintah nagari. Skala prioritas dalam memberikan bantuan khusus penanganan covid-19 seharusnya berbasis kepada dampak yang ditimbulkan akibat pandemi tersebut bukan berbasis data yang sudah ada sebelumnya, karena pandemi memberikan dampak yang tidak sama bagi masyarakat. Masyarakat yang terdampak paling buruk akibat pandemi seharusnya menjadi prioritas utama menerima bantuan khusus penanganan covid-19. Namun kenyataannya,
40\% pekerja tidak pernah menerima bantuan sama sekali dari pihak manapun, padahal mereka terdampak cukup parah akibat pandemi covid-19.

\section{DAFTAR KEPUSTAKAAN}

Ahmad, T., Haroon, Baig, M., \& Hui, J. (2020). Coronavirus Disease 2019 (Covid-19) pandemic and economic impact. Pakistan Journal of Medical Sciences, 36(COVID19-S4), S73-S78. https://doi.org/10.12669/pjms.36. COVID19-S4.2638

Azka, R. M. (2020, April 16). Sektor Transportasi Terancam Kolaps, Tiga Hal Ini Jadi Penyebabnya. Https://Ekonomi.Bisnis.Com/. Retrieved from https://ekonomi.bisnis. com/read/20200416/98/1228385/sektortransportasi-terancam-kolaps-tiga-hal-inijadi-penyebabnya

Dixon, S., McDonald, S., \& Roberts, J. (2002). The impact of HIV and AIDS on Africa's economic development. British Medical Journal, 324(7331), 232-234. https://doi. org/10.1136/bmj.324.7331.232

Elci, C. (2006). The Impact of HPAI of the H5N1 Strain on Economies of Affected Countries. International Conference on Human and Economic Resources, Izmir, 104-117. Retrieved from http://citeseerx.ist.psu.edu/ viewdoc/download?doi=10.1.1.104.4924\&a mp;rep=rep1\&amp;type=pdf\#page $=102$

Ezimma K., N., Ifeanyi E., O., \& Clara, A. C. (2020). Informal Sector and Nigerian Economic Prospects: The Covid-19 Experience. European Journal of Business and 
VOLUME 4, NOMOR 2, DESEMBER 2020

Management Research, 5(4), 1-5. https:// doi.org/10.24018/ejbmr.2020.5.4.397

Nicola, M., Alsafi, Z., Sohrabi, C., Kerwan, A., Aljabir, A., Iosifidisc, C., ... Agha, R. (2020). The Socio-Economic Implications of the Coronavirus Ppandemic (COVID-19): A Review. International Journal of Surgery, 78, 185-193.

Ozili, P. K., \& Arun, T. (2020). Spillover of COVID-19: Impact on the Global Economy. SSRN Electronic Journal. https://doi.org/10.2139/ ssrn.3562570

Perdana, A. B., N, A., Fathin, A., Ranggajati, A., W, A. D., S, D. R., ... W, Y. M. (2020). Policy Analysis: Melindungi Pekerja Rentan di Masa (dan Pasca) Pandemi Covid-19. In Institute of Governance and Public Affairs Fisipol UGM \& Forbil Institute. https://doi.org/10.1017/ CB09781107415324.004

Qiu, W., Chu, C., Mao, A., \& Wu, J. (2018). The Impacts on Health, Society, and Economy of SARS and H7N9 Outbreaks in China: A Case Comparison Study. Journal of Environmental and Public Health, 1-7. https://doi. org/10.1155/2018/2710185

Smith, K. M., Machalaba, C. C., Seifman, R., Feferholtz, Y., \& Karesh, W. B. (2019). Infectious Disease and Economics: The Case for Considering Multi-sectoral Impacts. One Health, 7. https://doi.org/10.1016/j. onehlt.2018.100080

Susilawati, S., Falefi, R., \& Purwoko, A. (2020). Impact of COVID-19's Pandemic on the Economy of Indonesia. Budapest International
Research and Critics Institute (BIRCI-Journal): Humanities and Social Sciences, 3(2), 11471156. https://doi.org/10.33258/birci. v3i2.954

Taufik, \& Ayuningtyas, E. A. (2020). Dampak Pandemi COVID-19 Terhadap Bisnis dan Eksistensi Platform Online. Jurnal Pengembangan Wiraswasta, 22(1), 21-32. https://doi.org/10.33370/jpw.v22i1389

Thomas, V. F. (2020). Ekonomi Kontraksi di Q2, Transportasi \& Akomodasi Paling Terpukul. Retrieved from tirto.id website: https://tirto. id/ekonomi-kontraksi-di-q2-transportasiakomodasi-paling-terpukul-fVQ1

Zuraya, N. (2020). Tiga Dampak Besar Pandemi Covid-19 bagi Ekonomi RI. Republika.Co.Id. Retrieved from https://republika.co.id/ berita/qdgt5p383/tiga-dampak-besarpandemi-covid19-bagi-ekonomi-ri 